\title{
PEMBUKUAN USAHA TANI PADI DI DESA LEUHAN KECAMATAN JOHAN PAHLAWAN KABUPATEN ACEH BARAT
}

\author{
${ }^{1)}$ Bagio, ${ }^{2)}$ Teuku Athaillah \\ Universitas Teuku Umar \\ ${ }^{1)}$ Email : bagio@utu.ac.id \\ ${ }^{2)}$ Email : athaillah.teuku@utu.ac.id
}

\begin{abstract}
ABSTRAK
Petani dalam usaha taninya tidak hanya berkepentingan dalam peningkatan produksinya, tetapi dapat meningkatkan pendapatan yang pada akhirnya juga meningkatkan keuntungan bagi petani padi sawah. Tujuan dalam usaha tani yaitu bagaimana petani dapat memperbesar hasil dalam hal ini memperoleh keuntungan sehingga kehidupan seluruh keluarganya menjadi lebih baik. Untuk mencapai tujuan ini petani selalu memperhitungkan untung ruginya walaupun tidak secara tertulis. Sebagian besar petani yang ada di Desa Leuhan belum mencatat secara rinci biaya-biaya apa saja yang telah dikeluarkan untuk usaha tani Padi, mulai dari pembersihan lahan, penanaman, pemeliharan, panen, dan pasca panen. Petani hanya mengetahui hasil penjualan akhir berupa gabah tanpa mencacat berapa biaya yang habis dikeluarkan selama berusaha tani. Sehingga belum diketahui pasti, pada akhir usaha tani padi sebenarnya petani mendapat keuntungan atau malah mengalami kerugian. Maka dari itu, perlu sekali yang namanya pembukuan usaha tani, sehingga petani dapat mengetahui seberapa besar perolehan pendapatan dari usaha tani padi tersebut. Sasaran peserta dari kegiatan pengabdian ini adalah kelompok petani usaha tani Padi dan masyarakat di Desa Leuhan, Kecamatan Johan pahlawan, Kabupaten Aceh Barat. Kegiatan ini dilakukan dengan metode pelatihan berupa pemaparan materi mengenai pembukuan usaha tani padi secara sederhana. Respon kelompok tani dalam pengabdian kepada masyarakat cukup baik dan kelompok tani antusias dalam menerima materi yang diberikan. Pembuatan pembukuan usaha tani padi telah disosialisasikan dengan baik kepada masyarakat khususnya petani padi. Tingkat pengetahuan dan pemahaman pembukuan usaha tani diserap dengan baik oleh para petani padi.
\end{abstract}

Kata kunci: Pembukuan, Petani, Usaha tani 


\section{PENDAHULUAN}

Provinsi Aceh merupakan salah satu daerah yang potensial untuk pengembangan usaha tani padi. Keadaan ini didukung oleh iklim, tanah, ketersediaan lahan dan kesesuaian lahan (Teuku Fadhla, 2017). Padi adalah tanaman paling penting dan terus dibudidayakan secara intensif oleh petani. padi merupakan tanaman pokok sehingga ketersediaan beras berpengaruh terhadap ketahanan pangan, dimana terjaminnya ketersediaan pangan bagi seluruh masyarakat sepanjang tahunnya secara berkelanjutan (sustainable). Selain itu, Padi juga merupakan salah satu komoditi pertanian tanaman pangan yang paling penting, sehingga keberlanjutan produksi baik dari segi kualitas maupun kuantitas sangat mempengaruhi ketersediaan pangan yang merupakan bahan pokok konsumsi masyarakat Indonesia. Oleh karena itu upaya meningkatkan produksi dapat dilakukan dengan adanya dukungan ilmu pengetahuan dan teknologi serta peningkatan sarana produksi yang berkualitas seperti benih/bibit unggul, pupuk dan obat-obatan.

Kabupaten Aceh Barat memiliki 12 kecamatan, dan seluruh kecamatan tersebut memiliki produksi padi. Berdasarkan Data BPS pada tahun 2017 luas lahan pangan padi yang terluas di Kabupaten Aceh Barat adalah di Kecamatan Kaway XVI (20\%) dari total areal yaitu 17.582,Ha, selanjutnya di ikuti oleh Kecamatan Arongan Lambalek $(13,1)$ Kecamatan Woyla $(12,5 \%)$, Kecamatan Woyla Barat (11\%), Kecamatan Samatiga (10\%), Kecamatan Pante Ceureumen (9\%), Kecamatan Meurebo (7\%), Kecamatan Bubon (6\%), sementara Kecamatan JohanPahlawan, Woyla Timur dan Panton Reu sebesar 3\%, terakhir Kecamatan Sungaimas (2\%).

Luas panen padi sepanjang tahun 2018 mencapai 23.770,5 hektar yang terdiri dari padi sawah sebesar 23.155,5 hektar dan padi ladang seluas 615 hektar. Jumlah ini menurun dibanding tahun sebelumnya. Dengan luas panen tersebut dihasilkan produksi padi X (ton GKG) sebesar 55.015 ton, dan Produksi Padi Setara Beras sebesar 31.530 ton. Dari sisi produktivitas cenderung stabil dibanding tahun sebelumnya. Curah hujan yang tinggi pada tahun tersebut sangat membantu pertanian masyarakat disini (Aceh Barat Dalam Angka, 2019).

Desa Leuhan merupakan salah satu desa dalam Kecamatan Johan Pahlawan Kabupaten Aceh Barat dengan usahatati Padi sebagai salah satu komoditi yang diperhitungkan dan mempunyai lahan cukup luas. Pada tahun 2018 luas tanam Padi seluas 878 ha, luas panen sebesar 934,2 ha, rata-rata produksi padi di Desa Leuhan sebanyak 4.297,32 ton dengan produktifitas 4,6 ton/ha. Jumlah penduduk Laki-laki 2.455 jiwa, perempuan 2.386 jiwa, dengan total penduduk 4.841 jiwa dan Seks Rasio 103, artinya bahwa dalam 100 penduduk perempuan terdapat 103 penduduk laki-laki.

Petani dalam usaha taninya tidak hanya berkepentingan dalam peningkatan produksinya, tetapi dapat meningkatkan pendapatan yang pada akhirnya juga meningkatkan keuntungan bagi petani padi sawah. Tujuan 
dalam usaha tani yaitu bagaimana petani dapat memperbesar hasil dalam hal ini memperoleh keuntungan sehingga kehidupan seluruh keluarganya menjadi lebih baik. Untuk mencapai tujuan ini petani selalu memperhitungkan untung ruginya walaupun tidak secara tertulis. Sebagian besar petani yang ada di Desa Leuhan belum mencatat secara rinci biaya-biaya apa saja yang telah dikeluarkan untuk usaha tani Padi, mulai dari pembersihan lahan, penanaman, pemeliharan, panen, dan pasca panen. Petani hanya mengetahui hasil penjualan akhir berupa gabah tanpa mencacat berapa biaya yang habis dikeluarkan selama berusaha tani. Sehingga belum diketahui pasti, pada akhir usaha tani padi sebenarnya petani mendapat keuntungan atau malah mengalami kerugian. Maka dari itu, perlu sekali yang namanya pembukuan usaha tani, sehingga petani dapat mengetahui seberapa besar perolehan pendapatan dari usaha tani padi tersebut.

Menurut Butar (2015) dalam Ratnasari (2017) Keberhasilan suatu usaha tani ditentukan oleh bagaimana manajemen yang dijalankan dalam usaha tersebut. Oleh karena itu, dalam usaha tani membutuhkan pengelolaan dengan baik yang dapat dilakukan dengan menerapkan prinsip - prinsip manajemen dan menjalankan semua fungsi manajemen mulai dari perencanaan, pengorganisasian, pelaksanaan, dan pengawasan dengan baik. Dengan demikian, perlu adanya pendekatan agribisnis dalam mengembangkan usaha tani, sehingga dapat menghasilkan keuntungan yang layak dan memadai (Putri, 2020). Hal ini didukung oleh penelitian yang lain bahwa pelatihan dapat meningkatkan produksi dan menurunkan biaya produksi (Mariyono dan Rachmansyah, 2010)

Tujuan kegiatan ini adalah untuk memperkenalkan dan mengajarkan kepada kelompok tani mengenai pembukuan usaha tani padi supaya petani dapat mengetahui secara pasti usaha tani yang di kerjakan memperoleh keuntungan atau sebaliknya mengalami kerugian. Adapun manfaat dari kegiatan ini adalah Membantu kelompok tani bagaiamana mencatat setiap pengeluaran dan pemasukan dari usaha tani yang di usahakan. Selain itu menjadi sebagai sumber informasi bagi para peneliti untuk penelitian lebih lanjut, pemerintah dalam menentukan kebijakan pertanian dan pihak-pihak untuk membantu petani menjadi mitra bisnisnya.

\section{METODE}

Sasaran peserta dari kegiatan pengabdian ini adalah kelompok petani usaha tani Padi dan masyarakat di Desa Leuhan, Kecamatan Johan pahlawan, Kabupaten Aceh Barat. Kegiatan ini dilakukan dengan metode pelatihan berupa pemaparan materi mengenai pembukuan usaha tani padi secara sederhana. Dalam melaksanakan program pengabdian masyarakat pada petani padi ada beberapa solusi yang coba ditawarkan 
kepada petani contoh outline pembukuan usaha tani secara sederhana serta memberikan keterangan tentang pentingnya pencatat usaha tani padi. Sehingga petani dapat mengetahui besar kecilnya keuntungan yang diperoleh selama melakukan usaha tani padi.

Target yang diharapkan dari pengabdian masyarakat ini adalah petani atau mengetahui apa itu pembukuan usaha tani dan manfaat pembukuan usaha tani. Serta petani mampu membuat pembukuan usaha tani padi secara sederhana. Sehingga petani dapat mengetahui secara pasti usaha tani yang di kerjakan memperoleh keuntungan atau sebaliknya mengalami kerugian. Luaran dari hasil kegiatan ini adalah Petani dapat melakukan pencatatan setiap biaya-biaya yang dikeluarkan ataupun pendapatan uahatani dengan membuat pembukuan usaha tani secara sederhana.

\section{HASIL DAN PEMBAHASAN}

Jumlah kelompok tani yang hadir pada acara pengabdian masyarakat sebanyak 20 orang, 8 orang lakilaki dan 12 orang perempuan. Rata-rata umur petani usia mulai dari 30 hingga 50 tahun. Salah satu indikator dalam menentukan produktivitas kerja dalam melakukan pengembangan usaha adalah tingkat umur, dimana umur petani yang berusia produktif lebih kuat bekerja, cekatan, mudah menerima inovasi baru bila dibandingkan tenaga kerja yang sudah memiliki usia yang relatif tua sering menolak inovasi baru.
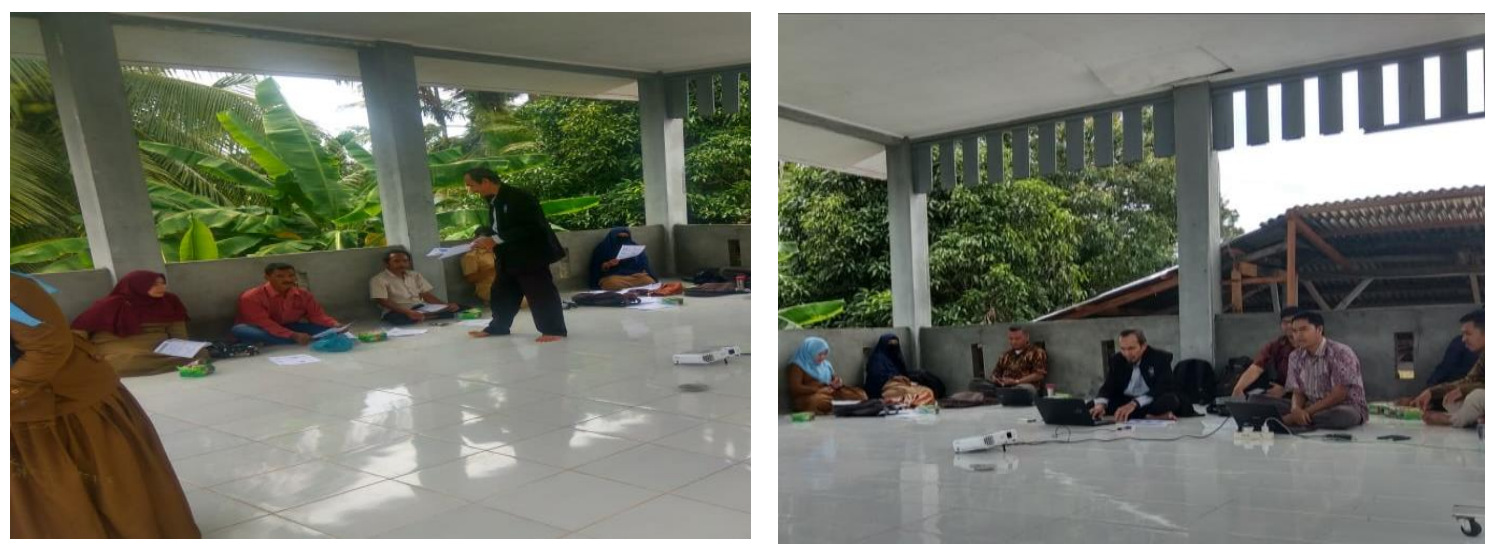

Gambar 1. Pemaparan Materi

Pelaksanaan pengabdian diadakan sebanyak dua sesi, yaitu sesi pemberian materi dengan menggunakan Power Point dan sesi praktik/diskusi pembuatan pembukuan sederhana usaha tani. Sesi pemberian materi yang pertama adalah tentang apa itu pembukuan usaha tani, pentingnya pembukuan 
ushatani dan manfaat pembukuan usaha tani. Selanjutnya menerangkan komponen-komponen apa saja yang perlu dimasukan dalam pembukuaan usaha tani, cara mencatat pengeluaran dan pendapatan usaha tani.

Pada sesi kedua, yaitu latihan langsung bagaimana cara mencatat biaya-biaya yang dikeluarkan seperti :

1) biaya sarana produksi usaha tani, yang terdiri dari sewa lahan, bibit, pupuk, pestisida dan lainnya

2) mencatat penggunaan tenaga kerja, walaupun tenaga kerja sendiri atau keluarga sendiri tetap dihitung dalam pembukuan usaha tani

3) mencatat semua peralatan yang digunakan dalam berusaha tani, mengetahui umur ekonomis perlatan serta menghitung nilai penyustan dari peralatan tersebut

4) selanjutnya menjumlahkan semua pengeluaran yang terdiri dari sarana produksi, biaya-biaya tenaga kerja dan biaya penyusutan alat.

5) mencatat jumlah produksi usaha tani padi untuk sekali musim tanam, selanjunnya dikalikan dengan harga jual gabah yang berlaku sekarang

6) tahap terakhir adalah mencari keuntungan dari usaha tani padi tersebut dengan cara : Jumlah pendapatan usaha tani padi - jumlah biaya yang dikluarkan.
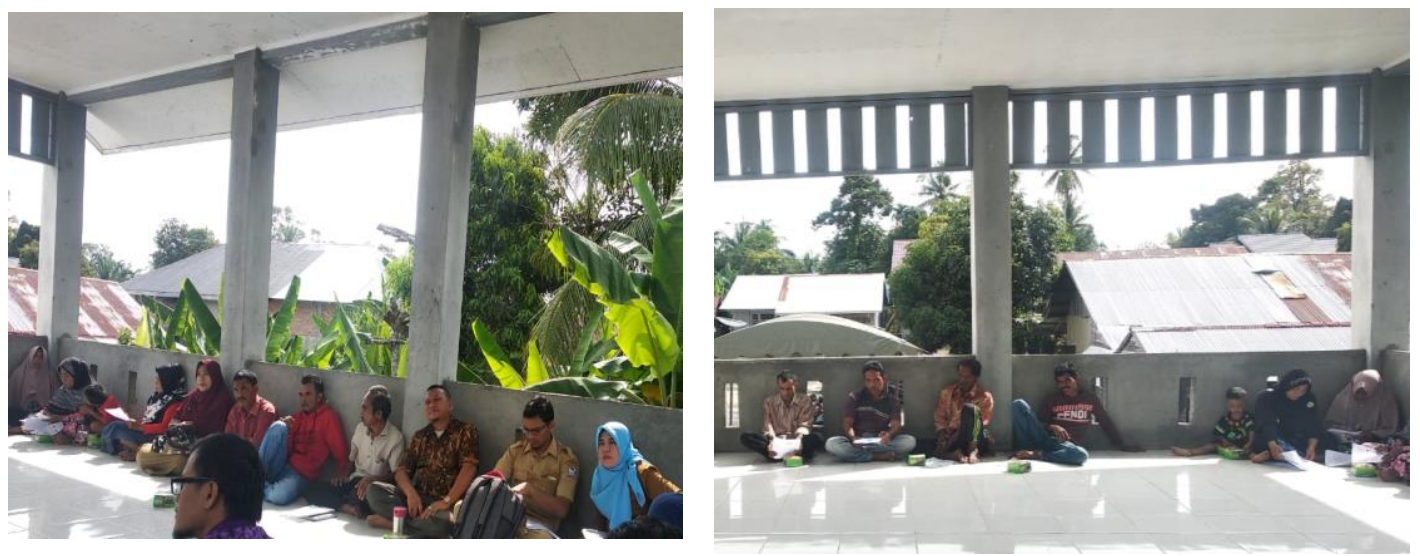

\section{Gambar 2. Peserta Tani}

Respon kelompok tani dalam pengabdian kepada masyarakat cukup baik dan kelompok tani antusias dalam menerima materi yang diberikan. Hal ini dapat dilihat dari banyaknya pertanyaan yang diajukan kepada pemateri dan memberikan respon positif terhadap materi yang diberikan sehingga kegiatan berakhir, karena selama ini petani sangat jarang sekali melakukan pembukuan pada usaha taninya. 

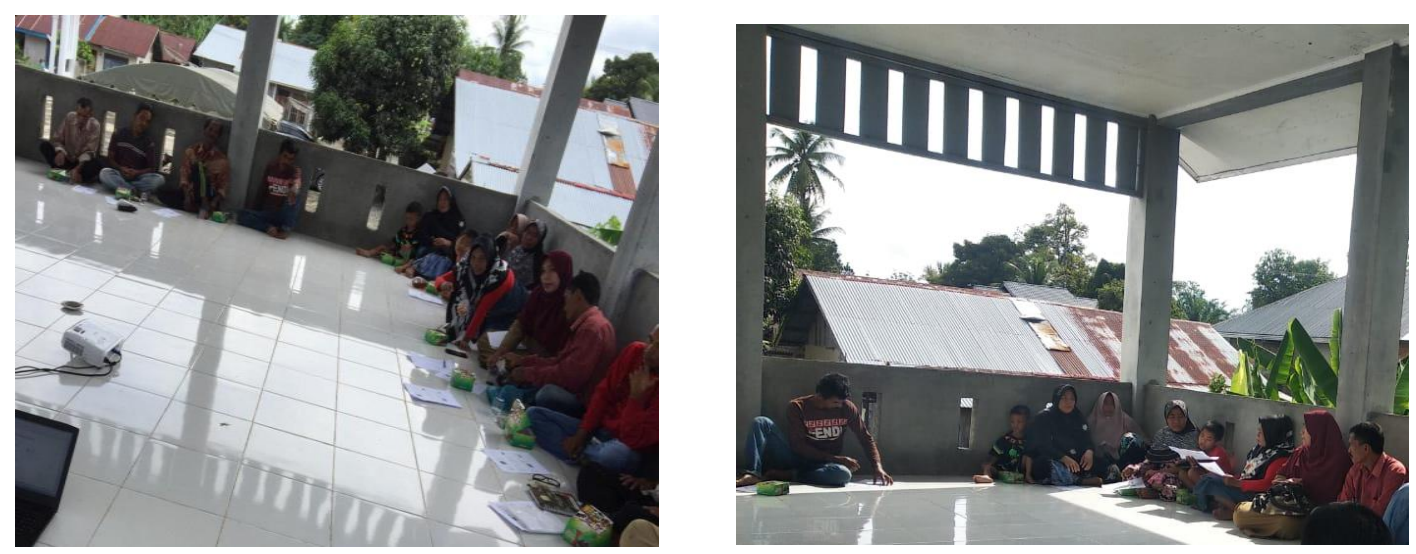

Gambar 3. Diskusi / Praktik Pembukuan Usaha tani

Evaluasi dilakukan dengan melihat pemahaman masyarakat terhadap pembukuan usaha tani. Hal ini terlihat dengan petani sudah mulai mampu untuk memilah mana itu yang dikatakan sarana produksi, biaya peralatan dan biaya tenaga kerja, selama ini petani tidak pernah menghitung biaya untuk tenaga kerja karena menggunakan tenaga kerja dalam keluarga.

\section{SIMPULAN}

Pembuatan pembukuan usaha tani padi telah disosialisasikan dengan baik kepada masyarakat khususnya petani padi. Tingkat pengetahuan dan pemahaman pembukuan usaha tani diserap dengan baik oleh para petani padi. Saran yang dapat diberikan dalam pelaksanaan program pengabdian masyarakat adalah petani padi dapat menerapkan pembukuan usaha tani secara sederhana, sehingga petani mampu untuk memenage keuangan dengan se efisien mungkin supaya usaha tani yang diusahakan memperoleh keuntungan yang maksimal. Selain itu, diperlukan dukungan oleh penyuluh setempat untuk memberikan arahan dan memotivasi petani untuk dapat meningkatkan produksi dan pendapatan.

\section{DAFTAR PUSTAKA}

BPS. 2019. Aceh Barat Dalam Angka 2019.

Mariyono, J. dan Rachmansyah, Y., 2010. Dampak Sekolah Lapangan Pengendalian Hama Terpadu Pada Produksi Kedelai Di Jawa Timur: Analisis Ekonomi. Dinamika Sosial Ekonomi, 6 (2): 129-144 
Putri M. G Ketty, I Nyoman Sirma, Lika Bernadina. 2020. Manajemen Usaha tani Terung Ungu Di Kelurahan Tuatuka Kecamatan Kupang Timur Kabupaten Kupang. Jurnal EXCELLENTIA Volume IX No 1 hal 50-57.

Ratnasari, Dian. 2017. Analisis Hubungan Manajemen Usaha tani Padi Sawah Dengan Tingkat Keberhasilan Gapoktan Serumpun (Studi Kasus Gapktan Serumpun Kota Gorontalo).

AGRINESIA. Vol 2 no.1, November 2017.

Teuku Fadhla. 2017. Analisis Manajemen Usaha Tani dalam Meningkatkan Pendapatan dan Produksi Padi Sawah di Kecamatan Tangan-Tangan Kab. Aceh Barat Daya. JURNAL VISIONER \& STRATEGIS Volume 6, Nomor 2. 